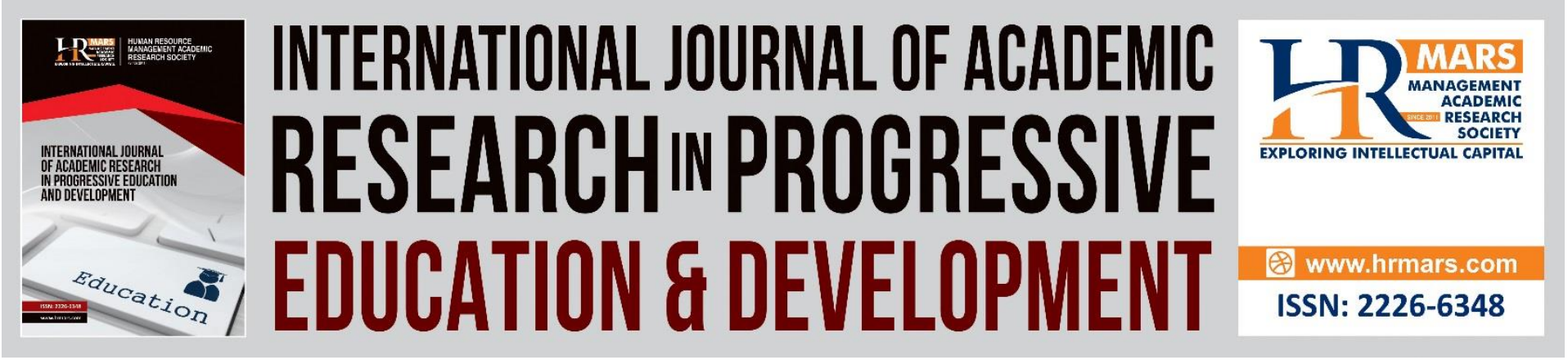

\title{
Measurement Model of Mathematics Intervention Based on the Learning Style of Students with Learning Disability (MIMGAP) Using Exploratory Factor Analysis (EFA)
}

Nafisah Baharom, Norshidah Mohamad Salleh \& Mohd Mokhtar Tahar

To Link this Article: http://dx.doi.org/10.6007/IJARPED/v10-i4/11751

DOI:10.6007/IJARPED/v10-i4/11751

Received: 01 September 2021, Revised: 03 October 2021, Accepted: 22 October 2021

Published Online: 15 November 2021

In-Text Citation: (Baharom et al., 2021)

To Cite this Article: Baharom, A., Salleh, N. M., \& Tahar, M. M. (2021). Measurement Model of Mathematics Intervention Based on the Learning Style of Students with Learning Disability (MIMGAP) Using Exploratory Factor Analysis (EFA). International Journal of Academic Research in Business and Social Sciences, 10(4), 114.

Copyright: (C) 2021 The Author(s)

Published by Human Resource Management Academic Research Society (www.hrmars.com)

This article is published under the Creative Commons Attribution (CC BY 4.0) license. Anyone may reproduce, distribute, translate and create derivative works of this article (for both commercial and non-commercial purposes), subject to full attribution to the original publication and authors. The full terms of this license may be seen

at: http://creativecommons.org/licences/by/4.0/legalcode

$$
\text { Vol. } 10 \text { (4) 2021, Pg. } 1 \text { - } 14
$$

Full Terms \& Conditions of access and use can be found at http://hrmars.com/index.php/pages/detail/publication-ethics 


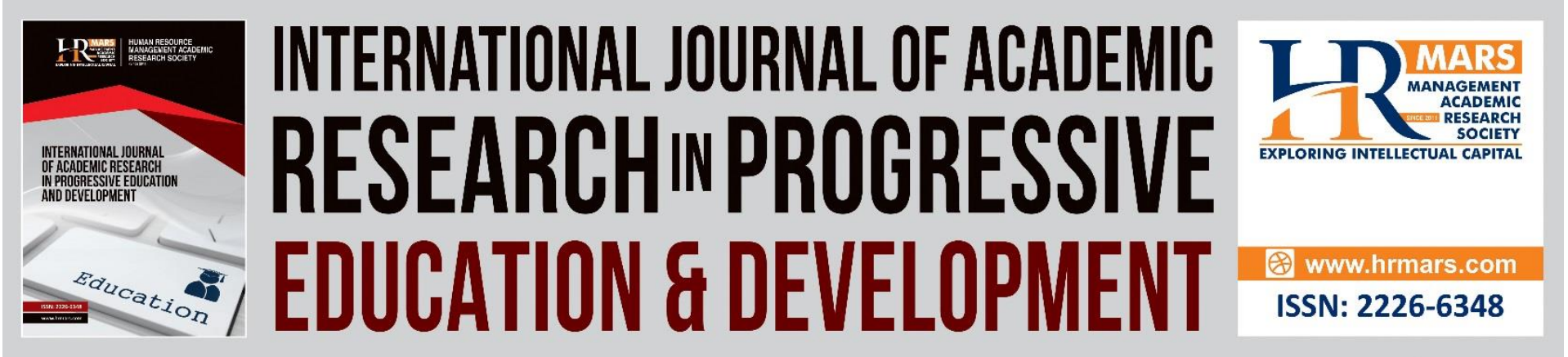

\title{
Measurement Model of Mathematics Intervention Based on the Learning Style of Students with Learning Disability (MIMGAP) Using Exploratory Factor Analysis (EFA)
}

\author{
Nafisah Baharom, Norshidah Mohamad Salleh \& Mohd \\ Mokhtar Tahar \\ National University of Malaysia, Malaysia
}

\begin{abstract}
Factor analysis is a statistical technique that has been widely used in psychology and social sciences, including the field of special education. The purpose of this study is to help researchers, educators, and students to understand the nature of exploratory factor analysis (EFA), specifically from the perspective of special education involving students with learning disability in mathematics. All items and factors identified through the EFA were used as inputs for the measurement model in second-generation structural equation modelling (SEM) techniques. This article presents five steps of exploratory factor analysis using SPSS, namely data examination technique, factor analysis, factor extraction, factor rotation and factor loading cutoff method. Pre-tests were conducted on 112 respondents, and items were analysed through Principal Component Analysis (PCA) using SPSS 26. Furthermore, the suitability of the data for EFA was measured through KMO and Bartlett's Sphericity tests. Based on the parallel analysis, four constructs were extracted for further investigation. This study demonstrates alternative guidance for students and researchers in intensively reviewing and re-testing items until satisfactory results are obtained. This study is also expected to help answer questions, fulfil objectives, determine analysis methods, and write research reports on children with learning disability.
\end{abstract}

Keywords: Student with Learning Disability, Mathematical Interventions, Exploratory Factor Analysis, Structure Equation Modeling, Parallel Analysis.

\section{Introduction}

Interventions for students with learning disabilities are important to reduce the impact of their disabilities, especially on topics that have proven scientifically difficult and can affect students' readiness to follow the teaching and learning process (Kementerian Pendidikan Malaysia, 2015). In line with the Reauthorisation of the Elementary and Secondary Education Act (ESEA) 2004, state and district accountability provisions were expanded to improve all students' learning performance and achievement, including those with difficulty mastering basic reading and numeracy skills. Researchers have employed various efforts to address the 
problem, including the Response to Intervention (RtI) Model (Preston et al., 2016). Starting from the literature review and research reference model (Rtl Model) related to the mathematical intervention of students with learning disabilities, studies have used EFA to study the relationship between the identified variables, namely screening, academic monitoring, data-based results and learning style of students with learning disabilities.

Factor analysis can be employed through exploratory factor analysis (EFA) and confirmation factor analysis (CFA) (Hair et al., 2014; Thompson, 2004). Although both methods are used to test for hidden or latent factors in data, both play different roles according to the research purpose, where EFA is used to construct theory and CFA is to test theory (Kline, 2016). Factor analysis plays an important role in social sciences and interdisciplinary studies (Yip \& Tse, 2019). Thus, this study uses factor analysis as a diagnostic tool to evaluate data related to the mathematical intervention of students with learning disabilities in line with the reference model that is the RtI model and learning style construct as the expected target construct. On this basis, EFA is used to reveal a set of latent factors (constructs) to reconstruct the observed complex data to present more meaningful and statistically acceptable data. This study is aimed to summarise the relationships between the variables and conceptualise the phenomenon (Hair et al., 2014) of mathematical interventions based on the learning styles of students with learning disabilities.

According to (Pashler et al., 2008), learning styles explain that each individual receives effective each other. Studies in several countries such as the UK and the Netherlands (Dekker et al., 2012), Spain (Ferrero et al., 2016), Portugal (Rato et al., 2013), Greece (PapadatouPastou et al., 2017) and China (Zhang et al., 2019) agree learning style affects student performance. A mathematics intervention is a program designed to help students facing difficulty mastering a particular math skill or task. Therefore, this study helps identify students who have difficulty mastering mathematical skills at an early stage and facilitate the provision of appropriate additional support materials regardless of the classification of disabilities.

\section{Problem Statement}

Implementing interventions in schools can help students who face problems in learning mathematics to overcome these problems. Past studies have shown that mathematical interventions can reduce skills gaps and prevent deficits that may occur in the future (Clements \& Sarama, 2007; Fuchs et al., 2002; Sophian, 2004). The success of mathematics interventions for students with learning disabilities has been extensively demonstrated through a variety of suggested methods and suggestions (Geary, 2013; Chard, et al., 2009; Jordan, et al., 2005; Jaspers et al., 2017; Kroesbergen \& Luit, 2003; Lemons et al., 2015; Suhaimin \& Mohamed, 2017). Nevertheless, there is still a gap of evidence (Jacobs, 2011; Miles 2017; Mueller-Bloch \& Kranz, 2015) that links the success of mathematical interventions for students with learning disabilities based on their learning styles.

In line with the the RtI intervention model which is the focus of this study, this study highlights the aspects of screening, progress monitoring and data-based decision in addition to other features that need to be considered when implementing mathematical interventions that the learning style of students with learning disabilities. This proposal is in line with a recent study by (Bawalsah \& Haddad, 2020) which found that students with learning disabilities can get more benefits in school when they are given the opportunity to learn according to learning styles adapted to various teaching strategies. These findings also indicate the relevance of issues related to students' learning style with learning disabilities to 
be given attention and discussed as current issues. The question that arises is how to help these students to reduce deficits that occur among their peers in similar situations. Therefore, an exploratory study of the characteristics of mathematics intervention based on the learning style of students with learning disabilities was conducted to help students with learning disabilities in mathematics to adapt to the practice of intervention in school.

This study is aimed to explore and develop psychometric properties to measure the characteristics of mathematical interventions based on the learning styles of students with learning disabilities. Therefore, this study expands the existing findings by validating the questionnaire on 112 mathematics teachers of students with learning disabilities. Considering the potential for correlations across MIMGaP instrument items, the researchers examined the data obtained using exploratory factor analysis. Thus, the purpose of this study is to examine the behaviour of the MIMGaP instrument items to identify teachers' perspectives on mathematical interventions for students with learning disabilities. This study aims to answer the following research questions:

1. What is the structure of factors/constructs for mathematics interventions for students with learning disabilities based on the perspectives of special education mathematics teachers?

\section{The Study}

Pilot studies are often conducted with a small sample (Polit \& Beck, 2014; Van Teijlingen \& Hundley, 2002) as leading to unsatisfactory results. Therefore, this study was conducted to review and re-test the items more intensively until satisfactory results were obtained. This led to the researcher's efforts to use the pre-test process in this study. The primary focus of most pre-tests is to address otherwise unresolved problems that ultimately contribute to measurement errors (Blair \& Conrad, 2011). The purpose of the pre-test questionnaire of this study was also to ascertain whether; (1) the question order is correct, (2) the question sequence is correct, (3) the respondent has clearly understood all the questions, (4) additional questions are required, or some questions should be omitted, (5) the instructions are clear and adequate and (6) all scales, or developed items, either adopted or adapted, are tested first to ensure whether the questions work appropriately in the new setting with new respondents (Kumar et al., 2013). Therefore, the pre-test study was conducted involving 112 special education mathematics teachers in Melaka using EFA Analysis.

\section{Methodology}

As the MIMGaP questionnaire instrument was adapted from previous models and studies, and additional constructs have been added, there is a need to validate the constructs and items of the questionnaire. For this purpose, an Exploratory Factor Analysis (EFA) approach has been used (Williams et al., 2010). In the context of this study, this approach was used to interpret the self-reporting of the MIMGaP questionnaire (Thompson, 2004). EFA used in this study was to find out the structure of measurement factors and the internal reliability of the MIMGaP questionnaire instrument. It involves the process of identifying inappropriate items that can then be removed. Essentially, since researchers do not predict the number of constructs to be measured (Costello \& Osborne, 2005) for MIMGaP items, comprehensive steps need to be taken to organise those items into smaller sets of factors.

Therefore, EFA is considered based on three main processes: determining the number of factors, choosing the extraction method, and choosing the rotation method. The process 
was also conducted to determine whether there is a relationship between latent variables and constructs (Rourke et al., 2013). A total of 112 respondents who are special education teachers with learning disabilities in Melaka. These respondents represent the general population of special education teachers with experience in implementing mathematics interventions in schools. Data obtained from the research questions were processed at the basic level using SPSS Statistics program 26. Descriptive statistical analysis was used for part A to obtain the mean, mode (frequency) and standard deviation of the respondents' background. SPSS Statistics 26 was used to run the data filtering process. Researchers ensure four types of data screening that need to be done using Smart-PLS (Razak \& Ali, 2020); (1) get rid of data that is not filled in completely (missing value), (2) get rid of data that is answered in a patent, (3) get rid of data that has an excessive value (outlier) and (4) conduct data normality tests. After the data were screened, analysis of the measurement model was initiated using Exploratory Factor Analysis (EFA).

\section{Findings and Discussion}

Exploratory factor analysis (EFA) is a very important statistical method for identifying the factors that can explain the correlation of a group of variables. Today, EFAs are becoming a fundamental tool in the theoretical evaluation and validation of measurement instruments (Haig, 2014; Henson \& Roberts, 2006; Izquierdo et al., 2014). The researcher conducted EFA analysis according to the following steps (Howard, 2015): (1) data examination technique, (2) factor analysis method, (3) factor extraction method, (4) factor rotation method; and (5) factor loading cutoff method.

\section{Data Examination Technique}

Data examination techniques begin with; (1) eliminating data that is not filled in completely or missing value, (2) eliminating data that is answered in a patent, (3) data that has an excessive value (outlier), and (4) test the normality of the data. Eliminating incomplete data can be done manually by examining each set of questionnaires. However, the researcher has set the 'Required' button for each questionnaire item in the google form provided. This step ensures that all respondents can answer the questionnaire without leaving even a single item. The next step, discarding the manually answered data by examining each set of questionnaires. The researcher removed the patented-filled questionnaires, for example, in the form of straight and zig-zag lines from the data set by the respondents. Table 1 shows the findings of the descriptive analysis for the pre-test. The descriptive data analysis in the pretest study was done to obtain information and insights on the demographic information of the respondents involved in this study. The demographic information included in this study are gender, position in school and teaching experience in special education (learning disabilities).

As shown Table 1, the distribution of data shows that 22 respondents (19.6\%) are male, while 90 respondents (80.4\%) are female. The demographic information of respondents' positions in schools showed that 94 respondents (83.9\%) are primary special education teachers for students with learning disabilities, 17 respondents (15.2\%) are senior assistant of special education, and 1 respondent $(0.9 \%)$ is an excellent special education teacher. Meanwhile, in terms of experience in teaching special education for primary students with learning disabilities, 8 (7.1\%), respondents have been teaching for 5 years, 38 teachers (33.9\%) have been teaching for 6 to 10 years, 49 people (43.8\%) have been teaching 
DEVELOPMENT

Vol. 10, No. 4, 2021, E-ISSN: 2226-6348 @ 2021 HRMARS

for 11 to 15 years, 11 respondents (9.8\%) have been teaching for 16 to 20 years a total of and 6 teachers $(5.4 \%)$ have been teaching for the 21 years and more.

Table 1. Descriptive Analysis of Respondent Demographics

\begin{tabular}{llcc}
\hline & Demographic Information & $\begin{array}{c}\text { Frequency } \\
\text { (f) }\end{array}$ & $\begin{array}{c}\text { Percentage } \\
\text { (\%) }\end{array}$ \\
\hline Gender & Male & 22 & 19.6 \\
& Female & 90 & 80.4 \\
Positions in schools & Special Education Teacher & 94 & 83.9 \\
& Senior Assistant Teacher of Special Education & 17 & 15.2 \\
& Excellent Teacher of Special Education & 1 & 0.9 \\
Experience in special & Less than 5 years & 8 & 7.1 \\
education (learning & 6 - 10 years & 38 & 33.9 \\
disability) & 11 -15 years & 49 & 43.8 \\
& 16 - 20 years & 11 & 9.8 \\
& 21 years and above & 6 & 5.4 \\
\hline
\end{tabular}

\section{Factor Analysis Method}

The correlation matrix is a matrix that contains the correlation coefficients of all pairs of variables in the study. This matrix was used to obtain the proximity value of the relationship between the study variables. This proximity value can perform several tests to see the conformity with the correlation value obtained from the factor analysis. At this stage, two things need to be done for factor analysis to be performed, namely, (1) determining the value of the Barlett Test of Sphericity, which is used to determine whether there is a significant correlation between the variables and (2) Keizer-Meyers-Oklin (KMO) Measure of Sampling Adequacy is used to measure the adequacy of the sample by comparing the value of the correlation coefficient obtained with the partial correlation coefficient. As a justification for the use of EFA in this study, according to (Hair et al. 2017) sampling adequacy measures and statistical tests to measure the extent to which relationships between variables are used. Thus, the Bartlett Test (Bartlett's Test of Sphericity) and Kaiser-Mayer-Olkin (KMO) can indicate a measure of sampling adequacy. The Bartlett test was significant at $p<0.05$ for EFAs considered appropriate and $\mathrm{KMO}$ values lower than 0.5 inappropriate. Thus, an exploratory factor analysis cannot be performed (Pallant, 2010). In line with (Pallant 2010), KMOs with values between 0.5 and 0.7 are satisfactory, 0.7 and 0.8 are good, 0.8 and 0.9 are very good, and above 0.9 are extremely good. 


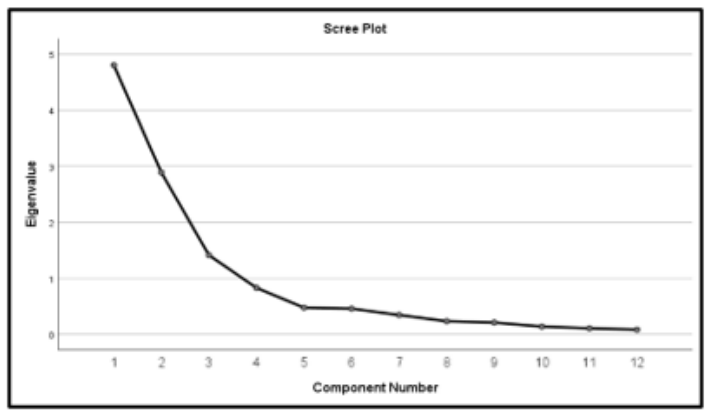

(a) Scree Plot of Construct A

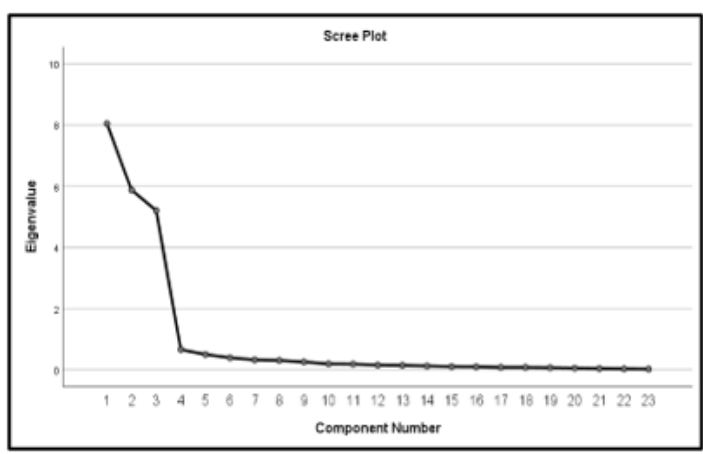

(c) Scree Plot of Construct C

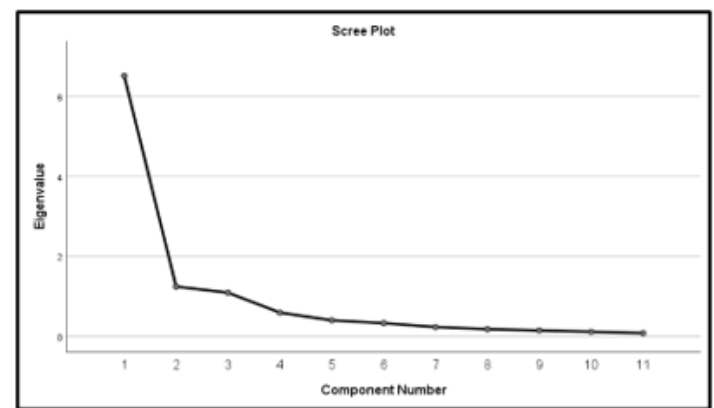

(b) Scree Plot of Construct B

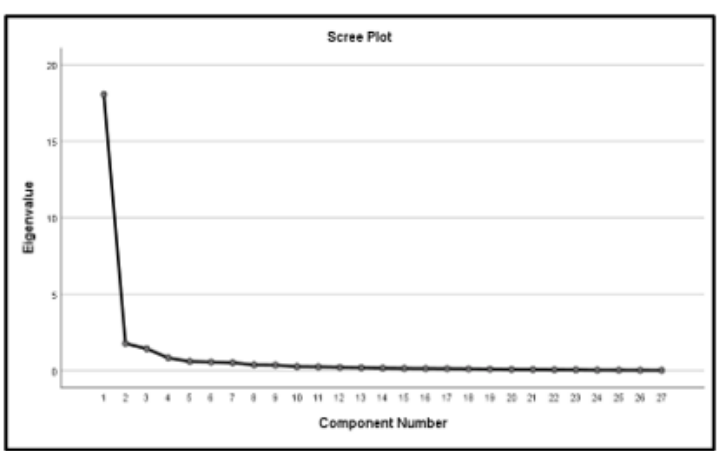

(d) Scree Plot of Construct D

Figure 1. Scree Plot of Each Construct

For construct $A$, the exploratory factor analysis was conducted to reinforce the items in the construct. The KMO value for construct $A$ is 0.795 , indicating that it is at a satisfactory level. In addition, the Barlett test is also significant at the value of $[\chi 2=1002.886, p<0.05]$. Preliminary results found high communality between $0.432-0.904$, and there are 3 factors with eigenvalues greater than 1.00 . This factor explains $80.28 \%$ of the total variance of which A1 (40.05\%), A2 (24.08\%) and A3 (11.78\%). Figure 1(a) illustrates each of the aspects in Construct A.

The analysis for Factor $B$ was conducted to reinforce the items in construct $B$. The KMO value for Construct $B$ is 0.873 , indicating a good and appropriate level. In addition, the Barlett test is significant at the value of [ $x 2=1043.402, p<0.05]$. Preliminary results found high communality between $0.714-0.884$. There are 3 factors with eigenvalues greater than 1.00 . This factor explains $80.56 \%$ of the total variance of which B1 $(59.24 \%)$, B2 (11.35\%) and B3 (9.97\%). Figure 1(b) illustrates each aspect in Construct B.

Meanwhile, exploratory factor analysis was conducted to reinforce the items in construct $\mathrm{C}$. The $\mathrm{KMO}$ value for construct $\mathrm{C}$ was 0.888 , indicating a reading at a good and appropriate level. In addition, the Barlett test was also significant at the value of $[\chi 2=$ $3544.629, \mathrm{p}<0.05]$. Preliminary results found high communality in the range between 0.647 - 0.949, and there are 3 factors with eigenvalues greater than 1.00 were found. This factor explains $83.13 \%$ of the total variance for C1 (34.96\%), C2 (25.54\%) and C3 (22.63\%). Figure 1(c) illustrates each aspect in Construct C.

The factor analysis was also conducted to reinforce the items in construct $D$. The KMO value for construct $D$ was 0.931 , indicating the readings were at a very good and appropriate level. In addition, the Barlett test is also significant at the value of [ $\chi 2=4045.475, p<.05$ ]. Preliminary results show a high communality between $0.650-0.895$, and there are 3 factors 
with eigenvalues greater than 1.00 . This factor explains $78.91 \%$ of the total variance of which D1 (66.91\%), D2 (6.64\%) and D3 (5.36\%). Figure 1(d) illustrates each aspect in Construct D.

\section{Factor Extraction Method}

At this stage, factor analysis was carried out to extract a group of variables with KMO $>0.5$ to form one or more factors. The methods used are the Principal Component Analysis and factor rotation with Varimax method (part from orthogonal) as shown in Table 2.

Table 2. Factor Extract

\begin{tabular}{|c|c|c|c|}
\hline Factor & Item & $\begin{array}{l}\text { Eigen } \\
\text { Value }\end{array}$ & $\begin{array}{c}\text { \% of } \\
\text { Variance }\end{array}$ \\
\hline A1 & PPA1/PPA2/PPA3/PP1/PP3/PP4 & 4.806 & 40.053 \\
\hline A2 & KMP2/KMP3/KMP4 & 2.890 & 24.080 \\
\hline A3 & PPB2/PPP2/PPP3 & 1.414 & 11.781 \\
\hline B1 & PPL1/PPL3/PPS1/PPS2/PPS3 & 6.517 & 59.24 \\
\hline B2 & SPP1/SPP3/SK1 & 1.249 & 11.35 \\
\hline B3 & PMA1/PMA2/PMA4 & 1.097 & 9.97 \\
\hline $\mathrm{C} 1$ & KDU1/KPT1/KPT2/KRPI/KRPI2/KKP1/KKP2/KFL1/KFL2/KFL3 & 8.041 & 34.96 \\
\hline $\mathrm{C} 2$ & PAD1/PAD2/PAD3/PAD4/PRPI1/PRPI2/PRPI3 & 5.876 & 25.54 \\
\hline $\mathrm{C} 3$ & KPRPI1/KPRPI2/KBL1/KBL2/KSS1/KSS2 & 5.205 & 22.63 \\
\hline D1 & $\begin{array}{c}\text { ASP1/ASP2/ASP3/ASP4/ABPS1/ABPS2/ABPS3/ABPP1/AB } \\
\text { PP2/ABPP3/AVAK1/AVAK2/AVAK3 }\end{array}$ & 18.065 & 66.91 \\
\hline $\mathrm{D} 2$ & SSM1/SSM2/SSM3/SSG1/SSG2/SSR1/SSR2/SSI1/SSI2 & 1.794 & 6.64 \\
\hline D3 & BVAK1/BVAK2/BVAK3/BVAK4/BVAK5 & 1.447 & 5.36 \\
\hline
\end{tabular}

\section{Factor Rotation Method}

The matrix factor was transformed into a simpler matrix in factor rotation, making it easier to interpret. In this analysis, factor rotation was performed by the varimax rotation method. The results interpretation was done by looking at the loading factor. A loading factor is a number that indicates the magnitude of the correlation between a variable with a factor of one, a factor of two, or a factor out of the three formed. The process of determining which variable will go into which factor was done by comparing the correlations in each row, as shown in Tables $3(a)$ to $3(d)$.

\section{Factor Loading Cut-off}

At this stage, the factors formed will be assigned a name based on the loading factor of a variable to the factors formed as shown in Table 3(a) to 3(d). 
INTERNATIONAL JOURNAL OF ACADEMIC RESEARCH IN PROGRESSIVE EDUCATION AND DEVELOPMENT

Vol. 10, No. 4, 2021, E-ISSN: 2226-6348 @ 2021 HRMARS

Table 3(b). Naming of Construct Factors (Progress Monitoring)

\begin{tabular}{|c|c|c|c|c|c|c|}
\hline Construct & Factor & Item & Component & Communalities & $\begin{array}{l}\text { Eigen } \\
\text { Value }\end{array}$ & $\begin{array}{c}\% \text { of } \\
\text { Variance }\end{array}$ \\
\hline \multirow{2}{*}{$\begin{array}{l}\text { Progress Monitoring } \\
\text { (B) }\end{array}$} & \multirow{2}{*}{$\begin{array}{l}\text { Report and } \\
\text { validation }\end{array}$} & PPL1 & .832 & .840 & \multirow[t]{5}{*}{6.517} & \multirow[t]{5}{*}{59.24} \\
\hline & & PPL3 & .814 & .765 & & \\
\hline \multirow[t]{11}{*}{11 Items } & \multirow{3}{*}{$\begin{array}{c}(\mathrm{B} 1) \\
5 \text { Items }\end{array}$} & PPS1 & .799 & .884 & & \\
\hline & & PPS2 & .849 & .868 & & \\
\hline & & PPS3 & .849 & .811 & & \\
\hline & \multirow{4}{*}{$\begin{array}{c}\text { Administrator, } \\
\text { Parental and } \\
\text { Other Support } \\
\text { (B2) } \\
3 \text { Items }\end{array}$} & SPP1 & .816 & .722 & \multirow[t]{4}{*}{1.249} & \multirow[t]{4}{*}{11.35} \\
\hline & & SPP3 & .839 & .844 & & \\
\hline & & SK1 & .823 & .837 & & \\
\hline & & & & & & \\
\hline & \multirow{3}{*}{$\begin{array}{l}\text { Monitoring } \\
\text { procedure } \\
\text { (B3) }\end{array}$} & PMA1 & .842 & .797 & \multirow[t]{4}{*}{1.097} & \multirow[t]{4}{*}{9.97} \\
\hline & & PMA2 & .834 & .780 & & \\
\hline & & PMA4 & .707 & .714 & & \\
\hline & 3 Items & & & & & \\
\hline
\end{tabular}

Table 3(a). Naming Of Construct Factors (Screening)

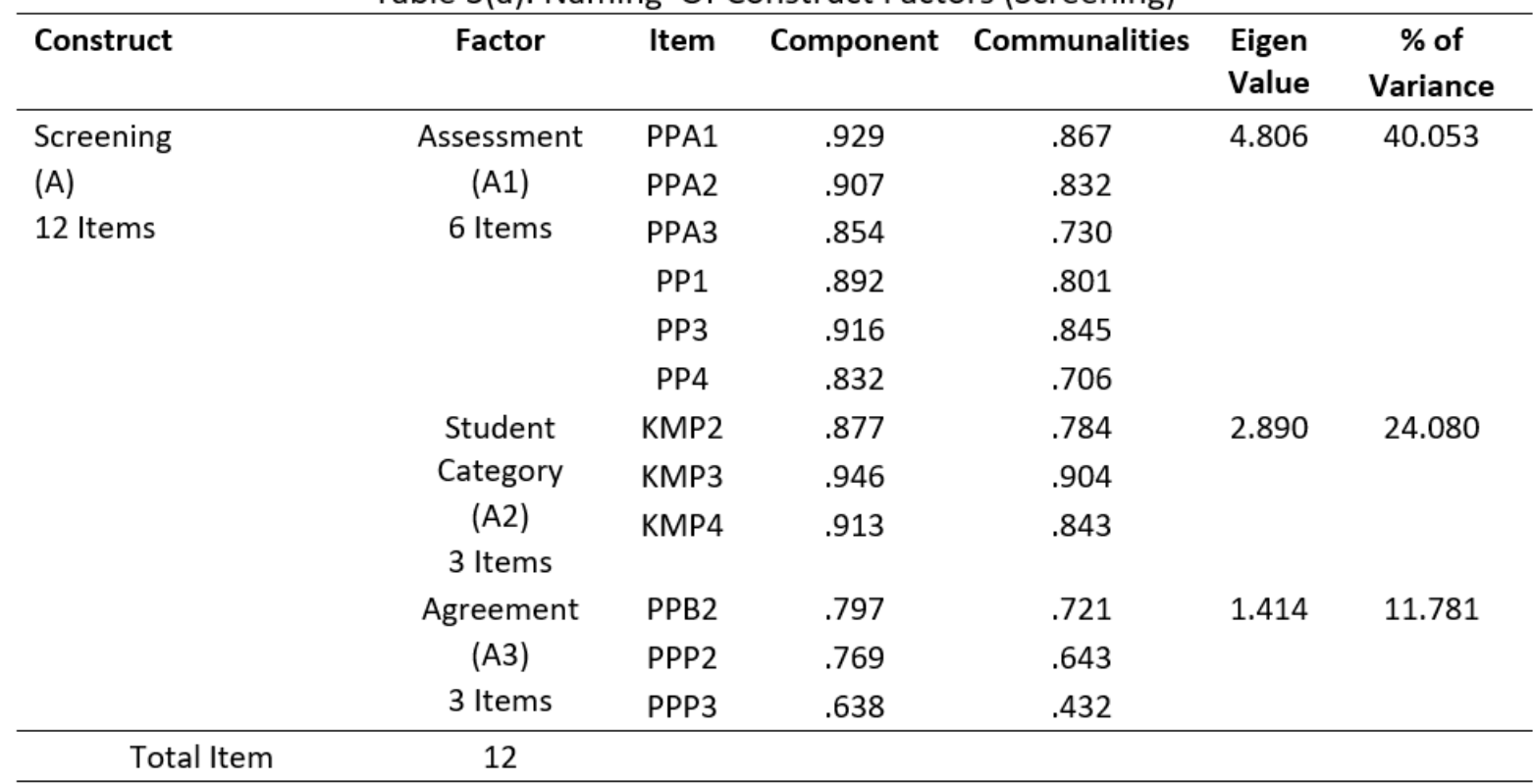


INTERNATIONAL JOURNAL OF ACADEMIC RESEARCH IN PROGRESSIVE EDUCATION AND DEVELOPMENT

Vol. 10, No. 4, 2021, E-ISSN: 2226-6348 @ 2021 HRMARS

Table 3(c). Naming of Construct Factors (Data-Based Decision)

\begin{tabular}{|c|c|c|c|c|c|c|}
\hline Construct & Factor & Item & Component & Communalities & $\begin{array}{l}\text { Eigen } \\
\text { Value }\end{array}$ & $\begin{array}{c}\% \text { of } \\
\text { Variance }\end{array}$ \\
\hline \multirow{23}{*}{$\begin{array}{l}\text { Data-Based } \\
\text { Decision } \\
\text { (C) } \\
23 \text { Items }\end{array}$} & \multirow{10}{*}{$\begin{array}{l}\text { Assessment } \\
\text { result } \\
(\mathrm{C} 1) \\
10 \text { Items }\end{array}$} & KDU1 & .888 & .793 & \multirow[t]{10}{*}{8.041} & \multirow[t]{10}{*}{34.96} \\
\hline & & KPT1 & .887 & .788 & & \\
\hline & & КPT2 & .804 & .647 & & \\
\hline & & KRPI1 & .872 & .779 & & \\
\hline & & KRPI2 & .858 & .745 & & \\
\hline & & KKP1 & .915 & .843 & & \\
\hline & & KKP2 & .901 & .813 & & \\
\hline & & KFL1 & .874 & .787 & & \\
\hline & & KFL2 & .912 & .843 & & \\
\hline & & KFL3 & .814 & .673 & & \\
\hline & \multirow{7}{*}{$\begin{array}{l}\text { Decision } \\
\text { making } \\
\text { procedure } \\
\text { (C2) } \\
7 \text { Items }\end{array}$} & PAD1 & .864 & .747 & \multirow[t]{7}{*}{5.876} & \multirow[t]{7}{*}{25.54} \\
\hline & & PAD2 & .940 & .885 & & \\
\hline & & PAD3 & .942 & .889 & & \\
\hline & & PAD4 & .954 & .913 & & \\
\hline & & PRPI1 & .908 & .828 & & \\
\hline & & PRPI2 & .910 & .834 & & \\
\hline & & PRPI3 & .893 & .807 & & \\
\hline & \multirow{6}{*}{$\begin{array}{l}\text { Intervention } \\
\text { needs } \\
\text { (C3) } \\
6 \text { Items }\end{array}$} & KPRPI1 & .960 & .927 & \multirow[t]{6}{*}{5.205} & \multirow[t]{6}{*}{22.63} \\
\hline & & KPRPI2 & .959 & .925 & & \\
\hline & & KBL1 & .974 & .949 & & \\
\hline & & KBL2 & .966 & .935 & & \\
\hline & & KSS1 & .959 & .924 & & \\
\hline & & KSS2 & .912 & .849 & & \\
\hline Total Item & 23 & & & & & \\
\hline
\end{tabular}


INTERNATIONAL JOURNAL OF ACADEMIC RESEARCH IN PROGRESSIVE EDUCATION AND DEVELOPMENT

Vol. 10, No. 4, 2021, E-ISSN: 2226-6348 @ 2021 HRMARS

Table 3(d). Naming of Construct Factors (Learning Style)

\begin{tabular}{|c|c|c|c|c|c|c|}
\hline Construct & Factor & Item & Component & Communalities & $\begin{array}{l}\text { Eigen } \\
\text { Value }\end{array}$ & $\begin{array}{c}\% \text { of } \\
\text { Variance }\end{array}$ \\
\hline \multirow{27}{*}{$\begin{array}{l}\text { Learning Style } \\
\text { (D) } \\
27 \text { Items }\end{array}$} & \multirow{13}{*}{$\begin{array}{l}\text { Intervention } \\
\text { Instructions } \\
\text { (D1) } \\
13 \text { Items }\end{array}$} & ASP1 & .714 & .650 & \multirow[t]{13}{*}{18.065} & \multirow[t]{13}{*}{66.91} \\
\hline & & ASP2 & .795 & .766 & & \\
\hline & & ASP3 & .825 & .832 & & \\
\hline & & ASP4 & .803 & .788 & & \\
\hline & & ABPS1 & .711 & .750 & & \\
\hline & & ABPS2 & .773 & .793 & & \\
\hline & & ABPS3 & .726 & .790 & & \\
\hline & & ABPP1 & .769 & .873 & & \\
\hline & & ABPP2 & .820 & .859 & & \\
\hline & & ABPP3 & .623 & .761 & & \\
\hline & & AVAK1 & .654 & .807 & & \\
\hline & & AVAK2 & .684 & .805 & & \\
\hline & & AVAK3 & .597 & .698 & & \\
\hline & \multirow{9}{*}{$\begin{array}{l}\text { Learning } \\
\text { Support } \\
\text { (D2) } \\
9 \text { Items }\end{array}$} & SSM1 & .592 & .752 & \multirow[t]{9}{*}{1.794} & \multirow[t]{9}{*}{6.64} \\
\hline & & SSM2 & .650 & .725 & & \\
\hline & & SSM3 & .644 & .731 & & \\
\hline & & SSG1 & .755 & .797 & & \\
\hline & & SSG2 & .737 & .685 & & \\
\hline & & SSR1 & .810 & .808 & & \\
\hline & & SSR2 & .816 & .749 & & \\
\hline & & SSI1 & .845 & .870 & & \\
\hline & & $\mathrm{SSI} 2$ & .737 & .781 & & \\
\hline & \multirow{5}{*}{$\begin{array}{l}\text { Learning } \\
\text { through } \\
\text { play (D3) } \\
5 \text { Items }\end{array}$} & BVAK1 & .791 & .854 & \multirow[t]{5}{*}{1.447} & \multirow[t]{5}{*}{5.36} \\
\hline & & BVAK2 & .833 & .895 & & \\
\hline & & BVAK3 & .757 & .814 & & \\
\hline & & BVAK4 & .764 & .860 & & \\
\hline & & BVAK5 & .795 & .816 & & \\
\hline
\end{tabular}

Total Item

27

\section{Conclusion}

Since students with learning disabilities have difficulty meeting the learning objectives set by the teacher, this article suggests that intensive mathematics interventions of an individual nature be implemented. However, effective implementation will require changes in the way instructional delivery and support systems among parties directly involved in implementing mathematical interventions such as teachers, parents, medical officers and schools. This is because the success of this proposal requires an in-depth understanding of the need to understand the mathematics learning style of students with learning disabilities. This article also involves exploratory factor analysis (EFA) conducted at the pre-test stage involving 112 respondents to identify factors that can explain the correlation of study variables. The analysis results have successfully formed four factors based on factor loading, namely screening, progress monitoring, data-based decision and learning style, with each factor consisting of 
three sub-factors. To determine some aspects related to the construction of the MIMGaP model, such as the emergence of new latent variables from the data affecting the learning style, the researcher suggested that further analysis using PLS-SEM be used. This advanced analysis also tested all 73 items related to their respective latent variables, either related to theories or new findings that were successfully explored from the data obtained.

\section{Acknowledgment}

We thank PP-FPEND-2021 for the support. The first author's grateful thank is extended to the Ministry of Education for the scholarship awarded for pursing doctoral degree. A sincere gratitude is hereby extended to Dr. Norshidah Mohamad Salleh and Dr. Mohd Mokhtar Tahar, as supervisors, both of whom have unceasingly helped in the completion of this paper.

\section{Corresponding Author}

Nafisah binti Baharom

National University of Malaysia, Malaysia, Centre of Education and Community Wellbeing, Faculty of Education, National University of Malaysia, 43600 Bangi, Selangor.

Email: p91678@siswa.ukm.edu.my

\section{References}

Bawalsah, J. A., \& Haddad, A. H. (2020). Preferred Learning Styles among Students with Learning Disabilities. International Journal of Education, 12(3), 119.

Blair, J., \& Conrad, F. (2011). Sample Size for Cognitive Interview Pretesting. The Public Opinion Quarterly, 75, 636-658.

Clements, D. H., \& Sarama, J. (2007). Effects of a Preschool Mathematics Curriculum: Summative Research on the Building Blocks Project. 38(2), 136-163.

Costello, A. B., \& Osborne, J. (2005). Best Practices in Exploratory Factor Analysis: Four Recommendations for Getting the Most From Your Analysis. Practical Assessment, Research \& Evaluation, 10, 1-9.

Dekker, S., Lee, N. C., Howard-Jones, P., \& Jolles, J. (2012). Neuromyths in Education: Prevalence and Predictors of Misconceptions Among Teachers. Frontiers in Psychology, 3(429), 1-8.

Ferrero, M., Garaizar, P., \& Vadillo, M. (2016). Neuromyths in Education: Prevalence among Spanish Teachers and an Exploration of Cross-Cultural Variation. Frontiers in Human Neuroscience, 10, 496.

Fuchs, L. S., Fuchs, D., Yazdian, L., \& Powell, S. R. (2002). Enhancing First-Grade Children's Mathematical Development with Peer-Assisted Learning Strategies. School Psychology Review, 31(4), 569-583.

Geary, D. C. (2013). Early Foundations for Mathematics Learning and Their Relations to Learning Disabilities. Current Directions in Psychological Science, 22(1), 23-27.

Gersten, R., Chard, D. J., Jayanthi, M., Baker, S. K., Morphy, P., \& Flojo, J. (2009). Mathematics Instruction for Students With Learning Disabilities: A Meta-Analysis of Instructional Components. Review of Educational Research, 79(3), 1202-1242.

Gersten, R., Jordan, N., \& Flojo, J. (2005). Early Identification and Interventions for Students With Mathematics Difficulties. Journal of Learning Disabilities, 38, 293-304.

Haig, B. (2014). Investigating the Psychological World: Scientific Method in the Behavioral Sciences. The MIT Press. 
Hair, J. F., Black, W. C., Babin, B. J., \& Anderson, R. E. (2014). Multivariate Data Analysis (8th Ed). Cengage Learning.

Hair, J. F., Hult, G. T. M., Ringle, C. M., \& Sarstedt, M. (2017). A Primer on Partial Least Squares Structural Equation Modeling (PLS-SEM) (2nd Ed).

Henson, R., \& Roberts, J. (2006). Use of Exploratory Factor Analysis in Published Research Common Errors and Some Comment on Improved Practice. Educational and Psychological Measurement - EDUC PSYCHOL MEAS, 66(3), 393-416.

Howard, M. (2015). A Review of Exploratory Factor Analysis (EFA) Decisions and Overview of Current Practices: What We Are Doing and How Can We Improve? International Journal of Human-Computer Interaction, 32, 1-49.

Izquierdo, I., Olea, J., \& Abad, F. J. (2014). Exploratory Factor Analysis in Validation Studies: Uses and Recommendations. Psicothema, 26(3), 395-400.

Jacobs, R. L. (2011). Developing a Research Problem and Purpose Statement. In DIm The Handbook of Scholarly Writing and Publishing, T. S. Rocco and T. Hatcher, San Francisco: Jossey-Bass (pp. 125-141).

Jaspers, K. E., McCleary, D. F., McCleary, L. N., \& Skinner, C. H. (2017). Evidence-based Interventions for Math Disabilities in Children and Adolescents. In DIm L. A. Theodore. Handbook of Evidence-based Interventions for Children and Adolescents. (pp. 99-110). Springer Publishing Company.

Kementerian Pendidikan Malaysia. (2015). Buku Panduan Pengoperasian Program Pendidikan Khas Integrasi (p. hlm 44). Bahagian Pendidikan Khas, KPM.

Kline, R. B. (2016). Principles and Practice of Structural Equation Modeling (4th Ed). Guilford Press.

Kroesbergen, E., \& Luit, J. E. H. (2003). Mathematics Interventions for Children with Special Educational Needs: A Meta-Analysis. In Remedial and Special Education (Vol. 24).

Kumar, M., Salim Abdul Talib, \& Ramayah, T. (2013). Business research methods. Oxford Fajar Sdn. Bhd.

Lemons, C., Powell, S., King, S., \& Davidson, K. (2015). Mathematics interventions for children and adolescents with Down syndrome: A research synthesis. Journal of Intellectual Disability Research, 59(8), 767-783.

Miles, D. (2017). A Taxonomy of Research Gaps: Identifying and Defining the Seven Research Gaps. Journal of Research Methods and Strategies, 1-10.

Mueller-Bloch, C., \& Kranz, J. (2015). A Framework for Rigorously Identifying Research Gaps in Qualitative Literature Reviews. International Conference on Information Systems, 119.

Pallant, J. (2010). Spss Survival Manual (4th ed). McGraw Hill.

Papadatou-Pastou, M., Haliou, E., \& Vlachos, F. (2017). Brain Knowledge and the Prevalence of Neuromyths among Prospective Teachers in Greece. Frontiers in Psychology, 8, 804.

Pashler, H., McDaniel, M., Rohrer, D., \& Bjork, R. (2008). Learning Styles: Concepts and Evidence. Psychological Science in the Public Interest, 9(3), 105-119.

Polit, D. F., \& Beck, C. T. (2014). Essentials of Nursing Research: Appraising Evidence for Nursing Practice. In The American Journal of Nursing (8th Ed, Vol. 79, Issue 9). Wolters Kluwer Health /Lippincott Williams \& Wilkins.

Preston, A. I., Wood, C. L., \& Stecker, P. M. (2016). Response to Intervention: Where It Came From and where It's Going. Preventing School Failure, 60(3), 173-182. 
Rato, J., Abreu, A. M., \& Castro-Caldas, A. (2013). Neuromyths in Education: What is Fact and What is Fiction for Portuguese Teachers? Educational Research, 55, 441-453.

Razak, M. R. A., \& Ali, E. (2020). Mudahnya SMART-PLS Modul Asas.

Rourke, N. O., O'rourke, H. L., \& Norm, L. H. (2013). A Step-by-Step Approach to Using SAS ${ }^{\circledR}$ for Factor Analysis and Structural Equation Modeling Second Edition A Step-by-Step Approach to Using $S A S{ }^{\circledR}$ for Factor Analysis and Structural Equation Modeling, Second Edition.

Sophian, C. (2004). Mathematics for the Future: Developing a Head Start Curriculum to Support Mathematics Learning. Early Childhood Research Quarterly, 19(1), 59-81.

Suhaimin, S. H., \& Mohamed, M. (2017). Intervention for Children with Specific Learning Disabilities (SpLD) in Mathematics Disorders: A Framework. Sains Humanika, 9(3-2), 83-90.

Thompson, B. (2004). Exploratory and Confirmatory Factor Analysis : Understanding Concepts and Applications. American Psychological Association.

Van Teijlingen, E., \& Hundley, V. (2002). The Importance of Pilot Studies. Nursing Standard (Royal College of Nursing (Great Britain) : 1987), 16, 33-36.

Williams, B., Onsman, A., \& Brown, T. (2010). Exploratory factor analysis: A five-step guide for novices. Australasian Journal of Paramedicine, 8(3).

Yip, T. H. J., \& Tse, W. S. (2019). Why Hope Can Reduce Negative Emotion? Could Psychosocial Resource be the Mediator? Psychology, Health \& Medicine, 24(2), 193-206.

Zhang, R., Jiang, Y., Dang, B., \& Zhou, A. (2019). Neuromyths in Chinese Classrooms: Evidence From Headmasters in an Underdeveloped Region of China. Frontiers in Education, 4, 8. 